\title{
THE ANALYTICAL DESCRIPTION OF FINAL PROBABILITIES FOR STATES OF QUEUING SYSTEMS WITH INPUT FLOW OF GROUPS OF REQUIREMENTS
}

\author{
Gorodnov V. P. - Dr. Sc., Professor, Professor of the National Academy of National Guard of Ukraine, Ukraine.
}

\begin{abstract}
Context. The management of many economic and other "service" systems of random flows of "requirements" is based on the prediction of their efficiency, based on an estimate of the system states probability distribution. In a number of important practical cases, the input flow may have random composition groups of requirements, which determined the applicability of linear algebra numerical methods for searching probabilities, and also made it difficult to build queuing systems that are effective in a range of conditions and made it impossible to obtain probability estimates for systems with an infinite number of places to wait for service. The objects of the study are Markov models of three types of queuing systems: with refusals, with a limited and with an unlimited number of places to wait in the conditions of the input flow of a random composition groups of requirements.

Objective. The goal of the work is to obtain an analytical description of the final state probabilities which are necessary to predict the values of efficiency indicators for three types of Markov multichannel queuing systems: with refusals, with a limited and with an unlimited number of places to wait in the conditions of the input flow of random composition groups of requirements.

Method. In the general case, the probabilities of states in queuing systems with input flow random groups of requirements are described by Kolmogorov differential equations. The Kolmogorov equations, in the stationary state of the queuing system, are transformed into a linearly dependent homogeneous system of algebraic equations. The final probabilities of the states of a queuing system can be found by numerically solving a system of equations using methods well known in linear algebra: complete exclusion, the inverse matrix, and the matrix method of Ramaswami [3], [38], which takes into account the repeating block structure of the system of equations matrix. The infinite number of unpredictable combinations for the set of numerical values of the considered queuing systems parameters makes it difficult to control the operation of such systems and to build systems that are effective in a range of conditions.

In queuing systems with an unlimited number of places to wait, the number of equations becomes infinite, and numerical methods become unsuitable for final probabilities searching and for solving problems of analysis, synthesis and control of queuing systems. Analytical expressions for the final probabilities of queuing systems are obtained by equivalent transformations of homogeneous systems of algebraic equations in the general case of each type of queuing system mentioned above.

Results. The obtained analytical expressions for the final probabilities of the queuing systems states for three noted system types are not previously known and therefore required verification of their correctness. Such a check was performed by the way of degenerate the flow of random groups of requirements in the input of the system to the simplest flow of requirements. As a result of verification, analytical expressions for the final probabilities of the considered systems states were automatically transformed into the corresponding well-known models of queuing systems with the simplest input flow of requirements. This effect allows us to consider the well-known models of queuing systems of the simplest input requirements flow - to be a particular case of the obtained models of queuing systems with an input flow of groups of requirements.

Conclusions. To further verify the correctness of the results and to assess the degree of influence of requirements random number in groups of input flow onto the system efficiency, a numerical example is given for the critical conditions of a constant intensity of requirements flow equal to the total performance of the system's service channels. In this case, only the average number of requirements in groups changed. The results of the numerical experiment testify in favor of the correctness of the obtained analytical expressions for the final probabilities and in favor of the possibility of their practical application in real queuing systems when solving problems of forecasting efficiency, as well as analyzing and synthesizing the parameters of real queuing systems.
\end{abstract}

KEYWORDS: Markov models, Queuing systems, Requirements groups.

\section{ABBREVIATIONS}

QS is a queuing system.

\section{NOMENCLATURE}

$L$ is a maximum number of requirements in a group; $M_{L} / M / n / m$ is a designation of queuing system;

$M_{L}$ is a designation of Poisson input flow of groups of requirements of random composition with the maximum number $L$ of requirements in a group;

$M$ is a designation of an exponential distribution of the random service time of each requirement;

$n$ is a number of identical channels (devices) in the queuing system;

$m$ is a number of places to wait;
$M_{L} / M / n / \infty$ is a designation of the queuing system noted above but with an infinite number of places to wait, it means $m=\infty$;

$M_{L} / M / n$ is a designation of the queuing system noted above but with no places to wait and it means with refusals;

$I$ is a flow intensity of requirements at the input of the queuing system;

$t$ is a current time;

$f_{1}()$ is a density distribution of the requirements flow at the input of the queuing system;

$e=2,71 \ldots$ is a second remarkable limit;

$T_{a v r}$ is a mathematical expectation of requirement's duration of service by the service device;

$\mu$ is a performance of one service device; 
$f_{2}()$ is a distribution density of service duration;

$i$ is the number of requirements in the group;

$\gamma$ is a number of occupied places to wait;

$a_{i}$ is a probability of a group consisting of exactly $i$

requirements at the input of the queuing system;

$\lambda$ is a parameter of requirements groups flow at the input of the queuing system;

$\lambda_{i}$ is a parameter of requirements groups input partial

flow that consists of exactly $i$ requirements in the group;

$p_{k}$ is a probability of a queuing system state in which

exactly $k$ devices are occupied;

$p_{n+\gamma}$ is a probability of a queuing system state in

which exactly $n$ devices are busy by servicing and exactly

$\gamma$ waiting places are occupied by requirements;

$\rho$ is a load factor of a queuing system with a simplest flow of requirements;

$\rho_{i}$ is a load factor of queuing system by a part of the input flow of requirements groups;

$f_{k}$ is a non-ordinary function, which deforms the probability $p_{k}$ of the $k$-th state of the queuing system when groups appear in the input flow of requirements;

$M_{\text {b.d }}$ is the mathematical expectation of the busy devices number;

$M[i]$ is the mathematical expectation of the requirements number in groups;

$A$ is an absolute system capacity;

$P_{\text {service }}$ is a service probability of queuing system;

$P_{\text {refusal }}$ is a refusal probability of service;

$S_{k}$ is a system state, at which exactly $k$ requirements are under maintenance;

$f_{k}$ is a non-ordinary function.

\section{INTRODUCTION}

In industry, science, medicine, commerce, information networks, management systems, and in other areas, there is often appears repeated massive demand (flow of requirements) for various services. To work out such requirements, the corresponding "service" systems are created.

The wide distribution and diversity of such systems has caused the need to develop appropriate models of queuing systems (QS) for solving problems of analysis, synthesis and control of real systems. The moments of occurrence of each requirement and the duration of its working out (service) are not known in advance (are random). Therefore, most models are stochastic

In real systems, as a rule, the conditions of the central limit theorem of A. Ya. Khinchin [18] are satisfied, and an input flow of requirements, that is close to the simplest one, is automatically generated. For such conditions, there are well-known models, for example, in [45]. However, requirements can often enter the system in groups with an unknown (random) quantity in the group. In queuing systems, shock loads occur, the effectiveness of systems decreases.

(C) Gorodnov V. P., 2019

DOI 10.15588/1607-3274-2019-4-3
To perform a forecast of the effectiveness in such system and in such conditions its possible only by numerical methods for specific numerical values of the conditions parameters. Unfortunately, the probability of "guessing" the exact values of the future set of continuous random variables (the parameters of the conditions) is strictly zero. Therefore, numerical analysis can be adequate to the real process only a posteriori, which sharply reduces its scientific significance and at the same time makes it important to search not numerical, but analytical descriptions of state probabilities and efficiency indicators of queuing systems with an input flow of groups with random composition of requirements.

The object of study is a steady-state process of servicing a flow of requirements groups in $M_{L} / M / n$ queuing systems with refusals, as well as with limited $M_{L} / M / n / m$ and with unlimited $M_{L} / M / n / \infty$ number of places to wait.

The subject of study is the distribution laws of the final state probabilities in queuing systems $M_{L} / M / n$ with refusals, as well as with limited $M_{L} / M / n / m$ and with unlimited $M_{L} / M / n / \infty$ number of places to wait and in input flow conditions groups of requirements with a random number of requirements in groups.

The purpose of the work is to obtain an analytical description of final probabilities for the general case of the $M_{L} / M / n$ model of a queuing system with refusals as well as for queuing systems with waiting $M_{L} / M / n / m$, $M_{L} / M / n / \infty$ and with a non-ordinary input flow of requirements. The noted final probabilities are a complete description of the systems operation and allow estimating the expected values of all known indicators of the queuing systems efficiency.

\section{PROBLEM STATEMENT}

The flow of non-ordinary requirements with intensity $I$ and density $f_{1}(t)=I e^{-I t}$ enters the queuing system. Service duration is random and has exponential distribution $f_{2}(t)=\mu e^{-\mu t}$. By virtue of the noted distribution densities, a Markov process with continuous time and discrete states arises in the system.

This paper relies on a system of statements about the properties of a non-ordinary (general stationary) flow [18, pp. 14, 40, 41], which we present without proof.

The stationary flow of time points for the arrival of groups of events without aftereffect is the simplest and is called the General Stationary Flow or non-ordinary flow.

Non-ordinary flow includes groups of $\boldsymbol{i}$ requirements $(i=1,2, \ldots, L)$ in a group. The flow can be determined by setting the probabilities distribution law $\left(a_{i}\right)$ of appearing exactly $\boldsymbol{i}$ requirements in any group of input flow. Then the flow parameter $\lambda$ will be less than the flow intension $(I, \lambda<I)$ and will include partial flows with parameters $\lambda_{i}$ :

$$
\lambda_{i}=\lambda a_{i} ; \quad \lambda=\sum_{i=1}^{L} \lambda_{i} ; \quad I=\sum_{i=1}^{L} i \cdot \lambda_{i} .
$$


A. Ya. Khinchin limit theorem [18] for random time intervals between groups of events in a non-ordinary flow is preserved and the form of the exponential distribution of time intervals is preserved too, but with the parameter $\lambda$ :

$$
f(t)=\lambda e^{-\lambda t}, \quad t>0
$$

At the same time, to fulfill equality $(\lambda=I)$ it is necessary and sufficient to have $a_{1}=1$. In this case, the flow of events becomes the simplest. For all other (nonordinary) stationary flows without an aftereffect, the intensity of the flow is always greater than its parameter $(I>\lambda)$.

\section{REVIEW OF THE LITERATURE}

The first model for calculating the part of calls that receive service at a telephone station was described by A. K. Erlang [12] in 1909. The process of the telephone station included the receipt and service of applications from subscribers to switch communication channels with other subscribers. The service of each application consisted in connecting the subscriber - the source of the application to the free channel of communication with the required subscriber. After the end of the call, the channel was released and could be used to service the next request. The application that arrived at the telephone station at the time when all channels were busy received a denial of service. The moments of receipt of applications and the end of their service were random.

The Erlang-developed model of the mass service system of requests at the telephone station turned out to be a universal tool for describing the processes of service in different systems and in different fields of human activity. Each of these areas and systems has its own peculiarities, which led to the development of more complex models and to the appearance of an independent scientific direction - the queuing theory.

Currently, queuing system models are being actively used for analysis, for predicting efficiency and for optimizing decisions made in various areas. These include the following areas: telecommunication networks $[8,13$, $23,25,42,43]$, socio-economic systems [11, 24], production systems $[2,21,32,46]$ and logistic systems $[15,34,35]$, computing systems $[5,19]$, traffic management systems $[1,4,17,37]$.

An interesting direction in the theory of queuing systems is the construction of models with an infinite number of devices, since it is these models that make it possible to describe complex technical systems for which the number of devices can be relatively large. For example, L. Brown, N. Gans, A. Mandelbaum, and A. Sakov [8] use such systems to simulate a call center in which agents provide telephone services almost no refusals. In such a company, customer service should start immediately. Therefore, the number of working operators should be large enough and should be monitored using the appropriate model.
Infinitely linear systems are also used as an approximation for multiline systems in cases where the probability of denial to service is negligible $[14,26,27$, $31,36,39]$.

At the initial stage, most studies of the queuing theory were performed under the assumption that the incoming flow of requests is the simplest $[9,40]$.

However, the development of computer and mobile systems has led to the need to create new mathematical models of requirements flows at the system input, which are not Poisson or non-ordinary flows. This was the reason for the increased interest in the study of systems with more complex incoming flows. Systems with nonPoisson flows were studied by such authors as G. P. Klimov [20], G. Sh. Tsitsiashvili [44], P. P. Bocharov, A. V. Pechinkin [6], A. N. Moiseev and A. A. Nazarov, [29], S. P. Moiseeva [30], E. A. Doorn and A. A. Jages [10], V. F. Matveev, V. G. Ushakov [28] and others.

So, in the book of Matveev V. F. and Ushakov V. G. [28] was obtained generating function of the requirements number in the system for which the incoming flow is a superposition of independent flows with the same number of requirements in packs. For non-Poisson input flows in a system with an unlimited number of service channels E. A. Doorn and A. A. Jagers [10] obtained estimates of the variance for the number of busy servers.

Another important direction in the development of the queuing theory is the study of the systems operation in the conditions of the incoming flow, which includes groups of requirements with previously unknown composition. Thus, groups of motorcade cars can arrive at a gas station, visitors can arrive at a roadside restaurant in groups at the time of vehicles arrival, and the customers flow to the hotel includes both single customers and groups of several people, families for example. Such a flow is called nonordinary.

A description of queuing system models with nonordinary input flow can be found in works of A. A. Shakhbazov [41], Jung-Shyr Wu and Jyh-Yeong Wang [16], N. O. Kutselay and S. V. Safonov [22], O. Yu. Bogoyavlenskaya [7], V. B. Monsik, A. A. Skrynnikov, and A. U. Fedotov, in works of A. V. Pechinkin [33] and A. G. Tatashev, M. Akhilgova, S. A. Shchebunyaev.

In the general case, the probabilities of states in queuing systems $M_{L} / M / n / m$ with a non-ordinary input flow of requirements are described by Kolmogorov differential equations.

The Kolmogorov equations, in the stationary state of the queuing system, are transformed into a linearly dependent system of algebraic equations. The final probabilities of the queuing system states can be found by numerically solving the system of algebraic equations using the methods well known in linear algebra [45] complete exclusion, inverse matrix, Kramer determinants. It should be noted that in this case the determinant of the algebraic equations system is always zero. Therefore, it is impossible to apply the Kramer determinant method directly. 
One of the variants of the noted system algebraic equations numerical solution is the well-known matrix geometric method of Ramaswami [3]. This method is characterized as a method for the analysis of quasi-birthdeath processes, continuous-time Markov chain whose transition rate matrix has a repetitive block structure. In this method, the final probabilities of the queuing system states are found using numerical calculations of the elements of the Neut's rate matrix [38].

Analytical description of models is sometimes possible to find for some performance indicators, as a rule, for single-channel systems (N. O. Kutselay and S. V. Safonov [22], O. Yu. Bogoyavlenskaya [7]) with a specific composition of requirements in input flow groups (V. B. Monsik, A. A. Skrynnikov, A. U. Fedotov and A. V. Pechinkin [33]).

The search for regularities that could provide an analytical description of the final probabilities in the general case of a queuing system with a non-ordinary input flow of requirements were engaged in A. A. Shakhbazov [41], Jung-Shyr Wu and Jyh-Yeong Wang [16]. In all the studies noted, it was concluded that the final probabilities sought could ultimately be found only by numerical methods for a specific flow structure.

One of the reasons for the lack of success in finding an analytical description of the final probabilities is that any change in the structure of the input flow of requirements or in the queuing system leads to a change in the composition and in the structure of the algebraic equations system. The number of options that appear is unlimited. Attempting to identify and describe regularities of emerging changes is faced with the need to take into account the enumerated set of combinations in the marked conditions, which goes beyond the scope of analysis.

However, if numerical methods allow to obtain the value of final probabilities for queuing systems $M_{L} / M / n / m$ with a limited number of service devices and with a limited number of waiting places, then for a situation with an unlimited number of them, for example, for a system $M_{L} / M / n / \infty$, numerical methods are not suitable due to the infinite number of algebraic equations.

In addition, the infinite number of variants of combinations for the numerical values of the $M_{L} / M / n / m$ system parameters makes it difficult to control the operation of such systems in real time.

As a result, the relevance of the task of finding an analytical description for the states final probabilities in queuing systems with a non-ordinary input flow of requirements becomes obvious.

\section{MATERIALS AND METHODS}

In order to demonstrate the logic of obtaining an analytical description of the final probabilities, let us consider a relatively easily visible example for the $\mathrm{M}_{2} / \mathrm{M} / \mathrm{n}$ system (Fig. 1).

At the entrance of the $\mathrm{M}_{2} / \mathrm{M} / \mathrm{n}$ queuing system with refusals, a non-ordinary flow is coming consisting of two ( $L=2$ ) partial flows with parameters $\lambda_{1}=\lambda a_{1}$ and $\lambda_{2}=\lambda a_{2}$.

The model's graph is shown in Fig. 1 and can be described by Kolmogorov differential equations system (3):

$$
\left.\begin{array}{l}
p_{0}^{\prime}(t)=-\lambda p_{0}(t)+\mu p_{1}(t) \\
p_{k}^{\prime}(t)=-(\lambda+k \mu) p_{k}(t)+\lambda_{1} p_{k-1}(t)+ \\
+\lambda_{2} p_{k-2}(t)+(k+1) \mu p_{k+1}(t), \quad 0 \leq k \leq n \\
p_{n}^{\prime}(t)=-n \mu p_{n}(t)+\lambda p_{n-1}(t)+\left(\lambda-\lambda_{1}\right) p_{n-2}(t) .
\end{array}\right\}
$$

Let's perform a sequential summation of the left and right sides of the equations in the system (3), we get:

$$
\begin{aligned}
\sum_{i=0}^{k} p_{i}^{\prime}(t)=\sum_{i=0}^{k}[ & -(\lambda+i \mu) p_{i}(t)+\lambda_{1} p_{i-1}(t)+ \\
& \left.+\lambda_{2} p_{i-2}(t)+(i+1) \mu p_{i+1}(t)\right], \quad 0 \leq k \leq n
\end{aligned}
$$

After identical transformations, the system of equations (4) takes the form:

$$
\sum_{i=0}^{k} p_{i}^{\prime}(t)=-k \mu p_{k}+\left(\lambda_{1}+\lambda_{2}\right) p_{k-1}+\lambda_{2} p_{k-2}, 0<k \leq n .
$$

For the conditions of the steady state from formulas (5) we find:

$$
k p_{k}=\frac{\lambda_{1}+\lambda_{2}}{\mu} p_{k-1}+\frac{\lambda_{2}}{\mu} p_{k-2}, 0<k \leq n .
$$

Let's call a group of requirements as a request and introduce the notation for the coefficients $\left(\rho_{i}, i=0 ; 1\right)$ of the system load by a part of the input flow of requests:

$$
\rho_{0}=\frac{\lambda_{1}+\lambda_{2}}{\mu} ; \quad \rho_{1}=\frac{\lambda_{2}}{\mu} .
$$

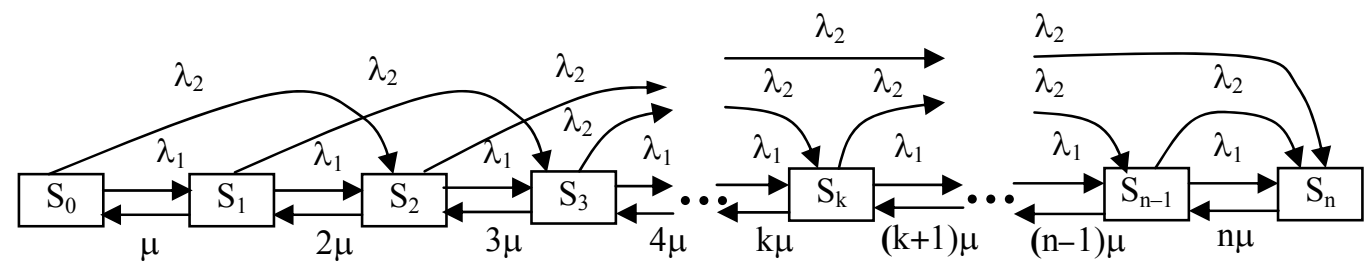

Figure 1 - The model graph of queuing system $\mathrm{M}_{2} / \mathrm{M} / \mathrm{n}$ with refusals 
Then we'll write down the equation:

$$
k p_{k}=\rho_{0} p_{k-1}+\rho_{1} p_{k-2}, \quad 0<k \leq n .
$$

For further reasoning, we recall the well-known Erlang formulas [12] for the queuing system $M / M / n$ with refusals:

$$
p_{k}=\frac{\rho^{k}}{k !} p_{0}, k=1, \ldots, n ; p_{0}=\left(\sum_{k=0}^{n} \frac{\rho^{k}}{k !}\right)^{-1} ; \rho=\frac{I}{\mu} .
$$

We'll seek the final probabilities $p_{k}$ of system states in a form close to well-known Erlang formulas (9):

$$
p_{k}=\frac{\rho_{0}^{k}}{k !} p_{0} f_{k}, \quad 0 \leq k \leq n .
$$

Substituting the formulas of the final probabilities (10) into the expression (8), we get:

$$
k\left(\frac{\rho_{0}^{k}}{k !}\right) p_{0} f_{k}=\rho_{0}\left(\frac{\rho_{0}^{k-1}}{(k-1) !}\right) p_{0} f_{k-1}+\rho_{1}\left(\frac{\rho_{0}^{k-2}}{(k-2) !}\right) p_{0} f_{k-2}
$$

After equivalent transformations we obtain a recurrent expression for the non-ordinary functions values:

$$
f_{k}=f_{k-1}+f_{k-2} \frac{\rho_{1}}{\rho_{0}^{2}}(k-1) .
$$

Then let's find the expression for the probability of the zero state using the probability normalization condition, in which we substitute formulas (10), we obtain:

$$
\begin{aligned}
\sum_{k=0}^{n} p_{k}=1 ; & \rightarrow \sum_{k=0}^{n} \frac{\rho_{0}^{k}}{k !} p_{0} f_{k}=p_{0}\left(\sum_{k=0}^{n} \frac{\rho_{0}^{k}}{k !} f_{k}\right)=1 ; \rightarrow \\
& \rightarrow p_{0}=\left(\sum_{k=0}^{n} \frac{\rho_{0}^{k}}{k !} f_{k}\right)^{-1} .
\end{aligned}
$$

To determine the value of the first non-ordinary function $\left(f_{0}\right)$, we substitute the value $k=0$ in formula (10) and then we get:

$$
p_{0}=p_{0} \cdot f_{0} .
$$

From equation (13) follows the equality $f_{0}=1$. The value of the non-ordinary function $\left(f_{1}\right)$ is found from formula (12) with the value $k=1$, we get:

$$
f_{1}=f_{1-1}+f_{1-2} \frac{\rho_{1}}{\rho_{0}^{2}} \times(1-1)=f_{0} .
$$

Thus, for $L=2$ the first two non-ordinary functions turned out to be equal to one unit: $f_{0}=f_{1}=1$. In this case, the analytical expressions become definite for all the desired final probabilities $p_{k}$, which make it possible to consider the problem is solved.

In the general case, the input of the queuing system receives a flow of groups of requirements, which consists

(C) Gorodnov V. P., 2019

DOI 10.15588/1607-3274-2019-4-3 of $L$ partial flows with parameters $\lambda_{i}=\lambda a_{i}, i=1, \ldots, L$. Then expressions (7) and (8) take the form:

$$
\begin{gathered}
\rho_{i}=\frac{1}{\mu} \sum_{j=1+i}^{L} \lambda_{j}, 0 \leq i<L \\
k p_{k}=\rho_{0} p_{k-1}+\rho_{1} p_{k-2}+\ldots+\rho_{k-1} p_{0} .
\end{gathered}
$$

After substitution (10) in (15) we get:

$$
\begin{gathered}
f_{k}=f_{k-1}+\sum_{i=2}^{k}\left[f_{k-i} \frac{\rho_{i-1}}{\rho_{0}^{i}} \prod_{j=1}^{i-1}(k-j)\right] ; k=2, \ldots, n ; \\
f_{0}=f_{1}=1 .
\end{gathered}
$$

In these conditions, for the general case of the $M_{L} / M / n$ queuing system with refusals, expressions of the final probabilities (10) and (13) are retained, but in which instead of the formula for the non-ordinary functions (12) it is necessary to use formula (16).

To verify the correctness of the solution obtained, we'll find the value of non-ordinary functions $f_{k}$ for the case of degeneration of a non-ordinary input flow of requirements into the simplest flow: $a_{1}=1 ; a_{i}=0, i>1$. In this case, the parameters of the partial flows of requests with two or more requirements are equal to zero $\left(\lambda_{i}=\lambda a_{i}=0, i>1\right)$. Then, from formulas (9), (1) and (15) it follows: $\rho_{0}=\rho ; \rho_{i}=0 ; i>0$.

Substituting the obtained values $\rho_{i}$ into formulas (12) and (16), taking into account the equality $f_{0}=f_{1}=1 \mathrm{we}$ see that, the second term vanishes and formulas (12) and (16) take the form:

$$
f_{k}=f_{k-1}=1 ; \quad k=1, \ldots, n .
$$

As a result, the expression (10) for the final probabilities is converted to the well-known Erlang formulas (9). This result argues in favor of correctness of the study and of the expressions obtained for the nonordinary functions (12), (16) and for final probabilities (10) in the $M_{L} / M / n$ system with a non-ordinary input flow and with refusals. At the same time, there are appearing grounds to consider the Erlang $M / M / n$ queuing system model as a particular case of the $M_{L} / M / n$ model.

The law of states' probability distribution in a queuing system allows finding calculation formulas for the following characteristics: the mathematical expectation of the busy devices number $M_{\mathrm{b} . \mathrm{d}}$; the mathematical expectation of the requirements number in groups $M[i]$; absolute system capacity $(A)$; service probability $\left(P_{\text {service }}\right)$ and for service refusal probability $\left(P_{\text {refusal }}\right)$ :

$$
\begin{gathered}
M_{b . d}=\sum_{k=1}^{n} k \cdot P_{k} ; \quad A=\mu \cdot M_{b . d} ; \\
P_{\text {service }}=\frac{A}{I} ; \quad P_{\text {refusal }}=1-P_{\text {service }} ; \\
M[i]=\sum_{i=1}^{L} i \cdot a_{i} ; \quad I=\lambda \cdot M[i] .
\end{gathered}
$$


In the next step let's consider the possibility of obtaining analytical expressions for the final probabilities of the queuing system with input flow of requirements groups $M_{L} / M / n / m$ and with $m$ places to wait.

Direct application of Kolmogorov's systems of differential equations [45] and then their algebraic analogues up to date has not allowed obtaining analytical expressions for the final probabilities of states in a queuing system with the input flow of requirements groups and with the waiting of $M_{L} / M / n / m$

Therefore, we'll first try to get analytical describing the final probabilities for the system $M_{2} / M / n / m$, then for analytical describing the final probabilities in the systems $M_{\mathrm{L}} / M / n / m$ and $M_{L} / M / n / \infty$.

Let's preserve all the conditions of the queuing system operation and all designations presented earlier and in relations (1) - (7).

Additionally, we note that if all $n$ devices in the system are occupied, then the next request gets in the queue and can be served by the first released device. The number of places in the queue is limited to $m$. If all places in the queue are occupied, the requirement is denied in service and it leaves the system. The marked graph of the queuing system model $M_{2} / M / n / m$ is shown in Fig. 2 .

For the $M_{2} / M / n / m$ queuing system (Fig. 2), the first group of Kolmogorov differential equations (20) corresponds to the absence of queue and coincides with the considered case (10)-(16) of the queuing system with refusals (Fig. 1).

The second group of Kolmogorov differential equations (21) corresponds to the condition of having a queue in the queuing system $M_{2} / M / n / m$ (Fig. 2). And in all together, we get:

$$
\left.\begin{array}{l}
p_{k}^{\prime}(t)=-(\lambda+k \mu) p_{k}(t)+\lambda_{1} p_{k-1}(t)+ \\
+\lambda_{2} p_{k-2}(t)+(k+1) \mu p_{k+1}(t), \quad 0 \leq k \leq n ; \\
p_{n+\gamma}^{\prime}(t)=-(\lambda+n \mu) p_{n+\gamma}(t)+\lambda_{1} p_{n+\gamma-1}(t)+ \\
+\lambda_{2} p_{n+\gamma-2}(t)+n \mu p_{n+\gamma+1}(t), \quad 0<\gamma<m ; \\
p_{n+m}^{\prime}(t)=-n \mu p_{n+m}(t)+\lambda p_{n+m-1}(t)+ \\
+\lambda_{2} p_{n+m-2}(t) .
\end{array}\right\}
$$

Let's do the summation of the marked differential equations (20) and (21).

$$
\begin{gathered}
\sum_{i=0}^{n+\gamma} p_{i}^{\prime}(t)=\sum_{i=0}^{n}\left[-(\lambda+i \mu) p_{i}(t)+\lambda_{1} p_{i-1}(t)+\right. \\
\left.+\lambda_{2} p_{i-2}(t)+(i+1) \mu p_{i+1}(t)\right]+ \\
+\sum_{j=1}^{\gamma}\left[-(\lambda+n \mu) p_{n+j}(t)+\lambda_{1} p_{n+j-1}(t)+\right. \\
\left.+\lambda_{2} p_{n+j-2}(t)+n \mu p_{n+j+1}(t)\right] ; \quad 0<\gamma<m ; \\
p_{n+m}^{\prime}(t)=-n \mu p_{n+m}(t)+\lambda p_{n+m-1}(t)+ \\
+\lambda_{2} p_{n+m-2}(t)
\end{gathered}
$$

The value of the first sum on the right-hand side of equality (22) can be determined using expression (5) for the conditions $k=n$ :

$$
\sum_{i=0}^{n} p_{i}^{\prime}(t)=-n \mu p_{n}+\left(\lambda_{1}+\lambda_{2}\right) p_{n-1}+\lambda_{2} p_{n-2} .
$$

Then, after identical transformations, the system of equations (22), for the conditions of stationary operation of the queuing system $M_{2} / M / n / m$ (Fig. 2), takes the form:

$$
0=-n \mu P_{n+\gamma}+\left(\lambda_{1}+\lambda_{2}\right) P_{\mathrm{n}+\gamma-1}+\lambda_{2} P_{\mathrm{n}+\gamma-2}, \quad \gamma=1, \ldots, m .
$$

Equality (24) can be transformed taking into account the introduced notation (7) of load factors:

$$
n P_{n+\gamma}=\rho_{0} P_{\mathrm{n}+\gamma-1}+\rho_{1} P_{\mathrm{n}+\gamma-2}, \quad \gamma=1, \ldots, m .
$$

The expression for the final probabilities of states $P_{n+\gamma}, \gamma=1, \ldots, m$ will be sought in the following form:

$$
\begin{gathered}
P_{n+\gamma}=\frac{\rho_{0}^{n}}{n !}\left(\frac{\rho_{0}}{n}\right)^{\gamma} P_{0} f_{n+\gamma}, \quad \gamma=1, \ldots, m ; \\
P_{k}=\frac{\rho_{0}^{k}}{k !} P_{0} f_{k}, \quad 0 \leq k \leq n .
\end{gathered}
$$

After substituting formulas (26) into (25) and performing equivalent transformations, we obtain a recurrent expression for calculating the non-ordinary functions:

$$
f_{n+\gamma}=f_{n+\gamma-1}+\frac{\rho_{1}}{\rho_{0}^{2}} \cdot n \cdot f_{n+\gamma-2}, \quad \gamma=1, \ldots, m .
$$

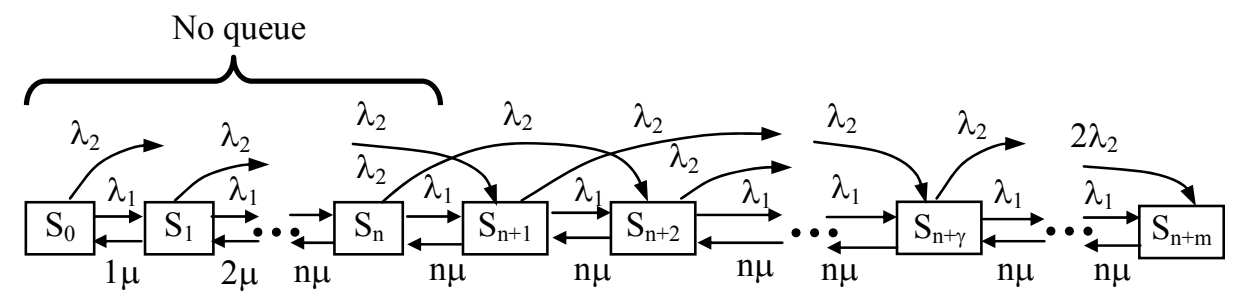

Figure 2 - Graph of the $\mathrm{M}_{2} / \mathrm{M} / \mathrm{n} / \mathrm{m}$ queuing system model 
The probability of the zero state in the $M_{2} / M / n / m$ model is found taking into account the probability normalization condition and the chosen form of representation of the final probabilities (26), we obtain:

$$
\begin{gathered}
\sum_{k=0}^{n} p_{k}+\sum_{\gamma=1}^{m} p_{n+\gamma}=1 ; \\
\rightarrow p_{0}=\left(\sum_{k=0}^{n} \frac{\rho_{0}^{k}}{k !} f_{k}+\frac{\rho_{0}^{n}}{n !} \sum_{\gamma=1}^{m}\left[\left(\frac{\rho_{0}}{n}\right)^{\gamma} f_{n+\gamma}\right]\right)^{-1} .
\end{gathered}
$$

Thus, the analytical description of the final probabilities for the queuing system $M_{2} / M / n / m$ with input flow of requirements groups includes expressions (7), (12), (26), (27), (28), where $f_{0}=f_{1}=1$. At the same time, performance indicators can be found using expressions (18) and (19). However, to get the mathematical expectation of the busy devices number $\left(M_{\mathrm{b} . \mathrm{d}}\right)$ we can use a more simple expression:

$$
M_{\mathrm{b} . \mathrm{d}}=n-\sum_{k=0}^{n}(n-k) p_{k} .
$$

In the general case of $M_{L} / M / n / m$ queuing system with waiting, the input of QS receives a flow of requirements groups, which consists of $L$ partial flows with parameters $\lambda_{i}=\lambda a_{i}, i=1, \ldots, L$. Then an expression (25) takes the form:

$$
\begin{aligned}
& n p_{n+\gamma}=\sum_{\mathrm{j}=0}^{\gamma-2} \rho_{\mathrm{j}} p_{(\mathrm{n}+\gamma)-1-j}+ \\
& +\sum_{k=0}^{n} \rho_{(\gamma-1)+\mathrm{k}} p_{\mathrm{n}-k}, \quad \gamma=1, \ldots, m .
\end{aligned}
$$

After substitution (26) into (30) we get:

$$
\begin{aligned}
& f_{n+\gamma}=f_{(n+\gamma)-1}+\sum_{j=1}^{\gamma-2}\left[f_{n+\gamma-1-j} \frac{\rho_{j}}{\rho_{0}^{j+1}} n^{j}\right]+ \\
& +\frac{n^{\gamma-1} n !}{\rho_{0}^{\gamma}} \sum_{k=0}^{n}\left[f_{n-k} \frac{\rho_{\gamma-1+k}}{\rho_{0}^{k}(n-k) !}\right], \quad 0<\gamma \leq m .
\end{aligned}
$$

In this general case of the $M_{L} / M / n / m$ queuing system with waiting, expressions of the final probabilities (26) and (28) are retained.

For the case of $M_{L} / M / n / \infty$ queuing system with waiting and with an infinite number of places to wait and with $(I<n \mu)$ there are no service refusals.

Absolute performance equals to intensity of input flow of requirements $(A=I)$. Then, to calculate the probability of the zero state of the queuing system and the mathematical expectation of the number of busy devices, instead of formulas (28) and (29), we find:

$$
M_{\mathrm{b} . \mathrm{d}}=\frac{I}{\mu} ; \quad p_{0}=\left(n-\frac{I}{\mu}\right) \cdot\left(\sum_{k=0}^{n}\left[(n-k) \cdot \frac{\rho_{0}^{k}}{k !} \cdot f_{k}\right]\right)^{-1} \text {. }
$$

From formula (32) it follows that the condition for the possible occurrence of a stationary mode in the queuing system $M_{L} / M / n / \infty$ is the inequality:

$$
I<(n \cdot \mu) \text {. }
$$

Inequality (33) determines the need to exceed the total performance of service devices over the flow intensity of the requirements at the system input. Otherwise, the average queue length in the system will increase indefinitely. All other formulas coincide with the formulas previously noted.

\section{EXPERIMENTS}

To evaluate the performance of a queuing system with refusals, the input flow of requirements groups sometimes is replaced with the simplest flow and the Erlang model $M / M / n(9)$ is used.

Let's consider the admissibility of such replacement using the example of the $M_{L} / M / n$ queuing system with the following parameters: $I=7$ [requirements/minute]; $n=7 ; L=8 ; \quad a_{i}=1 / L, i=1, \ldots, L ; \mu=1$ minute $\left.^{-1}\right]$. In such a system, the total performance of service devices coincides with the intensity of the input requirements flow $(I=n \cdot \mu)$. Therefore, in the case of deterministic input flow, all requirements must be served. The marked graph of the model is presented in Fig. 3.

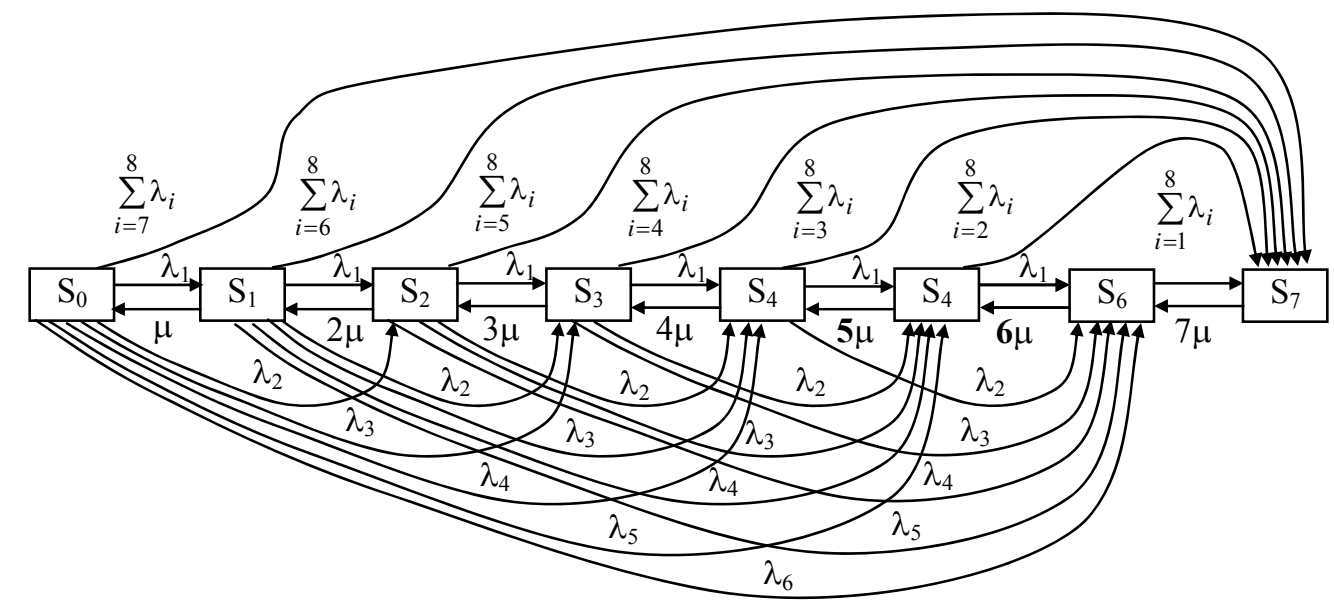

Figure 3 - The model graph of queuing system $\mathrm{M}_{\mathrm{L}} / \mathrm{M} / \mathrm{n}$ with refusals $(n=7 ; L=8)$ 
The probabilities of the model states (Fig. 3) in the steady state are described by the formulas (1), (10), (13), (15) and (16). These formulas we repeat for ease of analysis:

$$
\begin{gathered}
\lambda_{i}=\lambda a_{i}, \quad i=1, \ldots, L ; \quad \lambda=\sum_{i=1}^{L} \lambda_{i} ; \quad I=\sum_{i=1}^{L} i \cdot \lambda_{i} ; \\
\rho_{i}=\frac{1}{\mu} \sum_{j=1+i}^{L} \lambda_{j}, \quad 0 \leq i<L ; \quad p_{k}=\frac{\rho_{0}^{k}}{k !} p_{0} f_{k}, 0 \leq k \leq n \\
p_{0}=\left(\sum_{k=0}^{n} \frac{\rho_{0}^{k}}{k !} f_{k}\right)^{-1} ; \quad f_{0}=f_{1}=1 ; \\
f_{k}=f_{k-1}+\sum_{i=2}^{k}\left[f_{k-i} \frac{\rho_{i-1}}{\rho_{0}^{i}} \prod_{j=1}^{i-1}(k-j)\right] ; \quad k=2, \ldots, n .
\end{gathered}
$$

\section{RESULTS}

Non-ordinary functions $f_{k}$ are described by formula (16) in the case of an example (Fig. 3) will take the following form:

$$
\begin{gathered}
f_{0}=f_{1}=1 ; \quad f_{2}=f_{1}+f_{0} \frac{\rho_{1}}{\rho_{0}^{2}}(2-1) ; \\
f_{3}=f_{2}+f_{1} \frac{\rho_{1}}{\rho_{0}^{2}}(3-1)+f_{0} \frac{\rho_{2}}{\rho_{0}^{3}}(3-1)(3-2) ; \\
f_{4}=f_{3}+f_{2} \frac{\rho_{1}}{\rho_{0}^{2}}(4-1)+f_{1} \frac{\rho_{2}}{\rho_{0}^{3}}(4-1)(4-2)+ \\
+f_{0} \frac{\rho_{3}}{\rho_{0}^{4}}(4-1)(4-2)(4-3) ; \\
f_{5}=f_{4}+f_{3} \frac{\rho_{1}}{\rho_{0}^{2}} \cdot 4+f_{2} \frac{\rho_{2}}{\rho_{0}^{3}} \cdot 4 \cdot 3+f_{1} \frac{\rho_{3}}{\rho_{0}^{4}} \cdot 4 \cdot 3 \cdot 2+ \\
+f_{0} \frac{\rho_{4}}{\rho_{0}^{5}} \cdot 4 \cdot 3 \cdot 2 \cdot 1 ; \\
f_{6}=f_{5}+f_{4} \frac{\rho_{1}}{\rho_{0}^{2}} \cdot 5+f_{3} \frac{\rho_{2}}{\rho_{0}^{3}} \cdot 20+f_{2} \frac{\rho_{3}}{\rho_{0}^{4}} \cdot 60+ \\
+f_{1} \frac{\rho_{4}}{\rho_{0}^{5}} \cdot 120+f_{0} \frac{\rho_{5}}{\rho_{0}^{6}} \cdot 120 ;
\end{gathered}
$$

$$
\begin{aligned}
& f_{7}=f_{6}+f_{5} \frac{\rho_{1}}{\rho_{0}^{2}} \cdot 6+f_{4} \frac{\rho_{2}}{\rho_{0}^{3}} \cdot 30+f_{3} \frac{\rho_{3}}{\rho_{0}^{4}} \cdot 120+ \\
& +f_{2} \frac{\rho_{4}}{\rho_{0}^{5}} \cdot 360+f_{1} \frac{\rho_{5}}{\rho_{0}^{6}} \cdot 720+f_{0} \frac{\rho_{6}}{\rho_{0}^{7}} \cdot 720 .
\end{aligned}
$$

We use formulas (9) and estimate the probabilities $\left(p_{k}\right)$ of the system states and the probability of servicing the requirements in the Erlang model for the conditions of the simplest input requirements flow with the parameters noted above ( $I=7$ [requirements/minute]; $\mu=1 ; n=7$ ). The calculated results of the final probabilities and probabilities of requirements servicing in the $M_{L} / M / n$ and $M / M / n$ queuing systems are presented in Table 1 , Table 2 (No. 1-36) and on Fig. 4. From the quantitative estimates (Table 1, Fig. 4a), we can draw the following conclusion.

\section{DISCUSSION}

The appearance of groups in the input requirements flow of the same intensity changes the probability distribution of the system states (Table 1 No. 27-34) and leads to a decrease in the probability of service (Table 1 No. $36 P_{\text {service } g r}=0.547$ ) compared with the probability of service in the Erlang model (Table1 No. 37-44 and Table 1 No. $45 P_{\text {service Er }}=0.751$ ).

The influence of the requirements groups' composition on the changes in the final probabilities is concentrated in values of the multiplicative (10) nonordinary functions (16) (Table 1 No.19-26). The noted discrepancies are increasing significantly with an increase in the maximum number of requirements in groups (Table 2, No. 4, No. 28-34, Fig. 4b). At the same time, the non-ordinary functions (Table 2 No. 19-26) allow

\begin{tabular}{|c|c|c|c|c|c|c|c|c|c|c|c|c|c|c|}
\hline \multicolumn{12}{|c|}{ Model $M_{L} / M / \mathrm{n}$ (names and values of model parameters) } & \multicolumn{3}{|c|}{ Model M/M/n } \\
\hline \# & Name & Value & \# & Name & Value & \# & Name & Value & $\#$ & Name & Value & \# & Name & Value \\
\hline 1 & $n$ & 7 & 10 & $M[i]$ & 4.5 & 19 & $\mathrm{f}_{0}$ & 1 & 28 & $\mathrm{P}_{1}$ & 0.105 & 37 & $\mathrm{P}_{0}$ & 0.002 \\
\hline 2 & $\mu$ & 1 & 11 & $\rho_{0}$ & 1.556 & 20 & $f_{1}$ & 1 & 29 & $\mathrm{P}_{2}$ & 0.128 & 38 & $P_{1}$ & 0.011 \\
\hline 3 & $I$ & 7 & 12 & $\rho_{1}$ & 1.361 & 21 & $f_{2}$ & 1.56 & 30 & $\mathrm{P}_{3}$ & 0.141 & 39 & $\mathrm{P}_{2}$ & 0.037 \\
\hline 4 & $L$ & 8 & 13 & $\rho_{2}$ & 1.167 & 22 & $\mathrm{f}_{3}$ & 3.31 & 31 & $\mathrm{P}_{4}$ & 0.145 & 40 & $\mathrm{P}_{3}$ & 0.087 \\
\hline 5 & $\lambda$ & 1.556 & 14 & $\rho_{3}$ & 0.972 & 23 & $\mathrm{f}_{4}$ & 8.8 & 32 & $\mathrm{P}_{5}$ & 0.144 & 41 & $\mathrm{P}_{4}$ & 0.152 \\
\hline 6 & $a_{i}$ & 0.125 & 15 & $\rho_{4}$ & 0.778 & 24 & $\mathrm{f}_{5}$ & 28.1 & 33 & $\mathrm{P}_{6}$ & 0.139 & 42 & $\mathrm{P}_{5}$ & 0.213 \\
\hline 7 & $\lambda_{\mathrm{i}}$ & 0.194 & 16 & $\rho_{5}$ & 0.583 & 25 & $\mathrm{f}_{6}$ & 104 & 34 & $\mathrm{P}_{7}$ & 0.129 & 43 & $\mathrm{P}_{6}$ & 0.249 \\
\hline 8 & $\rho=I / \mu$ & 7 & 17 & $\rho_{6}$ & 0.389 & 26 & $\mathrm{f}_{7}$ & 437 & 35 & $\mathrm{M}_{\mathrm{b} . \mathrm{d}}$ & 5.26 & 44 & $\mathrm{P}_{7}$ & 0.249 \\
\hline 9 & $I / n \mu$ & 1 & 18 & $\rho_{7}$ & 0.194 & 27 & $\mathrm{P}_{0}$ & 0.068 & 36 & $P_{\text {serv.gr }}$ & 0.547 & 45 & $P_{\text {serv.Er }}$ & 0.751 \\
\hline
\end{tabular}
taking into account changes in the probabilities of the queuing system states and can be increased up to values of $10^{5}$ and more (Table 2 No. 26).

We watch, that an increasing in the mathematical expectation of the requirements number in groups (Table 2 No. 37-45, Fig. 5) leads to an asymptotic tending to zero of the requirements servicing probability.

In the natural environment, an analogue of such processes can be the interaction of a group of predators (service devices) with large groups of victims - grassfeeding animals on land or fish in the sea.

Table 1 - Evaluation of the influence of requirements groups in the input flow on the state's probabilities in the queuing system (see Fig. 3. Fig. 4a) 
Table 2 - Estimation of the tendency in the probabilities of states in the queuing system $M_{L} / M / n$ and the probability $\mathrm{P}_{\text {service }}$ of the requirements servicing with an increase in the maximum number of requirements $L$ in groups of input flow (see Fig. 4b. Fig. 5)

\begin{tabular}{|c|c|c|c|c|c|c|c|c|c|c|c|c|c|c|c|c|c|}
\hline \multicolumn{12}{|c|}{ Calculation of the state's probabilities in $\mathrm{QS} M_{L} / M / n$ (see Fig. 4 b) } & \multicolumn{6}{|c|}{$P_{\text {serv.gr }}=f(M[i]) \quad$ (see Fig. 5 ) } \\
\hline \# & Name & Value & \# & Name & Value & \# & Name & Value & \# & Name & Value & \# & $L$ & $a_{\mathrm{i}}$ & $\lambda_{\mathrm{i}}$ & $\mathrm{M}[\mathrm{i}]$ & $P_{\text {serv }}$ \\
\hline 11 & $n$ & & 10 & $\mathrm{M}[\mathrm{i}]$ & 18 & 19 & $f_{0}$ & & 28 & $\overline{P_{1}}$ & 0.16 & 37 & 1 & 1 & 7 & & 0.751 \\
\hline 2 & $\mu$ & 1 & 11 & $\rho_{0}$ & 0.39 & 20 & $f_{1}$ & 1 & 29 & $P_{2}$ & 0.11 & 38 & 5 & 0.22 & 2.333 & & 0.618 \\
\hline 3 & I & 7 & 12 & $\rho_{1}$ & 38 & 21 & $f_{2}$ & 3.86 & 30 & $P_{3}$ & 0.09 & 39 & 10 & 0.1 & 1.273 & 5.5 & \begin{tabular}{|l|}
0.507 \\
\end{tabular} \\
\hline 4 & $L$ & 35 & 13 & $\rho_{2}$ & 0.37 & 22 & $f_{3}$ & 25.9 & 31 & $P_{4}$ & 0.07 & 40 & 15 & $0.067 \mathrm{C}$ & 0.875 & 8 & 0.429 \\
\hline 5 & $\lambda$ & 0.39 & 14 & $\rho_{3}$ & 0.36 & 23 & $f_{4}$ & 247 & 32 & $P_{5}$ & 0.06 & 41 & 20 & 0.05 & 0.667 & 10.5 & 0.371 \\
\hline 6 & $a_{i}=1 / L$ & 0.0286 & 15 & $\rho_{4}$ & 0.34 & 24 & $f_{5}$ & 3066 & 33 & $P_{6}$ & 0.05 & 42 & 25 & 0.04 & 0.538 & 13 & 0.327 \\
\hline 7 & $\lambda_{i}$ & 0.0111 & 16 & $\rho_{5}$ & 0.33 & 25 & $f_{6}$ & 46746 & 34 & $\mathrm{P}_{7}$ & 0.05 & 43 & 30 & 0.033 & 0.452 & 15.5 & 0.293 \\
\hline 8 & $\mathrm{I} / \mu$ & 7 & 17 & $\rho_{6}$ & 0.32 & 26 & $f_{7}$ & 845472 & 35 & $M_{b . d}$ & 1.69 & 44 & 35 & 0.029 & 0.389 & 18 & 0.265 \\
\hline 9 & $\mathrm{I} / n \mu$ & & 18 & $\rho_{7}$ & 0.31 & 27 & $\mathrm{P}_{0}$ & 0.41 & 36 & $P_{\text {serv }}$ & 0.27 & & 40 & 0.025 & 0.341 & 20.5 & 0.242 \\
\hline
\end{tabular}
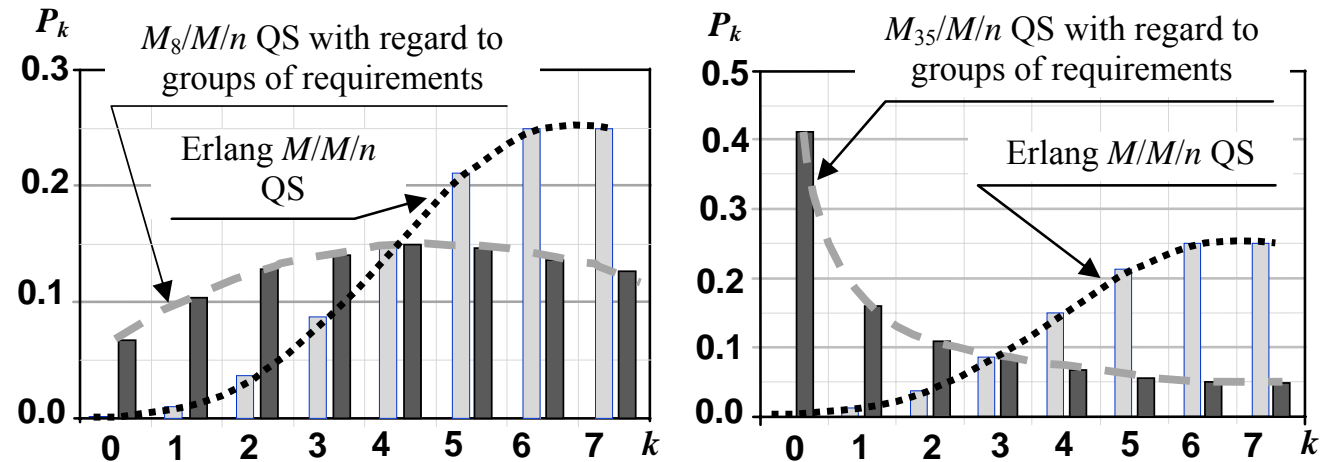

Figure 4 - Probabilities $P_{k}$ of the states of the same queuing system - without taking into account the groups of requirements in the input flow (Erlang model $M / M / n$ ) and - taking into account the groups of requirements in the composition of the real input flow with at the same intensity $I=7$ [requirements $/$ minute $]\left(n=7 ; \mu=1\left[\right.\right.$ minute $\left.\left.^{-1}\right] ; P_{\text {service Erlang }}=0.751\right)$

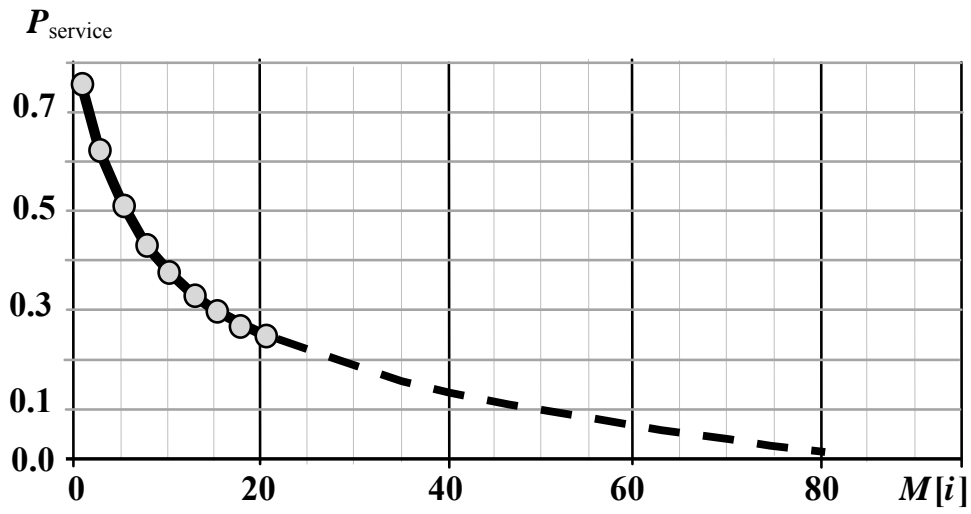

Figure 5 - The change in the probability of service $\left(\boldsymbol{P}_{\text {service}}\right)$ in the queuing system $M_{L} / M / n$ with constant flow intensity of groups of requirements ( $I=7$ requirements/minute; $n=7 ; \mu=1$ [minute ${ }^{-1}$ ]; $\boldsymbol{a}_{i}=1 / L$ ) and with increasing mathematical expectation $M[i]$ of the number of requirements in groups

The increase in the number of victims reduces the probability of their death (service), which can be evaluated within the model $M_{L} / M / n$.

The considered features determine the need to take into account the composition of groups in the input flow of requirements when making assessments and when managing the corresponding queuing systems.

\section{CONCLUSIONS}

In the course of solving an actual scientific problem, analytical expressions were first obtained for the final state probabilities in $M_{L} / M / n$ queuing systems with (C) Gorodnov V. P., 2019 DOI 10.15588/1607-3274-2019-4-0 refusals, as well as with limited $M_{L} / M / n / m$ and with unlimited $M_{L} / M / n / \infty$ number of places to wait in the conditions of input flows of requirements groups with a random number of requirements in groups.

The scientific novelty of obtained results consists in creating possibilities for predicting the efficiency of three types of Markov queuing systems with an input flow of requirements groups with random requirements number in groups. At the same time, the well-known Markov models of servicing the simplest flow of requirements turned out to be a particular case of the considered models with an input flow of groups of requirements. In new formulas, all 
the features of servicing groups of requirements are localized in recurrent expressions for non-ordinary functions.

The practical significance of obtained results consists in creating conditions for the directed solution of problems of analysis, synthesis and control of Markov queuing systems in the general case of an input flow of requirements groups with a random number of requirements in groups. The obtained formulas for calculating the values of the non-ordinary functions are recurrent and convenient for practical calculations. The numerical values of these functions clearly show the deformation of the state's final probabilities in queuing systems with an input flow of requirements groups compared to the known queuing systems with the simplest input flow of requirements.

Prospects for further research may include building models of queuing systems of requirements groups with the departure of requirements from the queue of queuing systems and models of systems with incomplete availability of service devices. Each of these systems is an actual model of real systems in the economy, in medicine, in modern communication systems and in other areas.

\section{REFERENCES}

1. Afanas'yeva L. G., Bulinskaya E. V. Matematicheskiye modeli transportnykh sistem, osnovannyye na teorii ocheredey, Trudy MFTI, 2010, Vol. 2, Issue 4, pp. 6-10.

2. Albey E., Bilge U., Uzsoy R. Multi-dimensional clearing functions for aggregate capacity modeling in multi-stage production systems, International Journal of Production Research, 2017, Vol. 55, Issue 14, pp. 4164-4179. DOI: https://doi.org/10.1080/00207543.2016.1257169/.

3. Asmussen S. R. Random Walks, Applied Probability and Queues. Stochastic Modelling and Applied Probability, 2003, Vol. 51, pp. 220-243. DOI: https://doi:10.1007/0-38721525-5 8. ISBN 978-0-387-00211-8/.

4. Assad A. A. Models for rail transportation, Transportation Research Part A: General, 1980, Vol. 14, Issue 3, pp. 205220. Access mode: DOI: https://doi.org/10.1016/01912607(80)90017-5/.

5. Balsamo S., De Nitto V Personè, Inverardi P. A review on queueing network models with finite capacity queues for software architecture performance prediction, Performance Evaluation, 2003, Vol. 51, Issue. 2, pp. 269-288. Access mode: DOI: https://doi.org/10.1016/S0166-5316(02)00099$8 /$.

6. Bocharov P. P., Pechinkin A. V. Teoriya massovogo obsluzhivaniya. Moscow, Izd-vo RUDN, 1995, $520 \mathrm{p}$

7. Bogoyavlenskaya O.Yu. Statsionarnoye raspredeleniye dliny ocheredi $\mathrm{v}$ sisteme $\mathrm{s}$ neordinarnym potokom i distsiplinoy razdeleniya protsessora, Trudy Petrozavodskogo gosudarstvennogo universiteta, seriya «Matematika», 1996, Vol. 3, pp. 3-10.

8. Brown L., Gans N., Mandelbaum A. et al. Statistical Analysis of a Telephone Call Center, Queueing-Science Perspective Journal of the American Statistical Association, 2005, Vol. 100, Issue 469, pp. 36-50. DOI: https://doi.org/10.1198/016214504000001808/.

9. D'Auria B. Stochastic decomposition of the $\mathrm{M} / \mathrm{G} / \infty$ queue in a random environment, Operations Research Letters, 2007, Vol. 35, pp. 805-812.

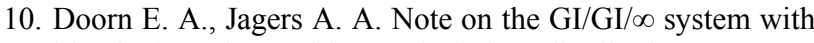
identical service and interarrival-time distributions, Journal of queueing systems, 2004, Vol. 47, pp. 45-52.

11. Ebadi M., Ahmadi-Javid A. Socio-economic design of control charts for monitoring service processes: a case study of a restaurant system, Journal Quality Technology \& Quantitative Management, 2018, Published online. DOI: https://doi.org/10.1080/16843703.2018.1519880/.

12. Erlang A. K. The Theory of Probabilities and Telephone Conversations, Nyt Tidsskrift for Mathematic Ser. B 20., 1909.

13. Gaydamaka Yu. V., Zaripova E. R., Samuilov K. E.Modeli obsluzhivaniya vyzovov $\mathrm{v}$ seti sotovoy podvizhnoy svyazi. Moscow, RUDN, 2008, 72 p.

14. Grachev V. V., Moiseev A. N., Nazarov A. A. et al Mnogofaznaya model' massovogo obsluzhivaniya sistemy raspredelennoy obrabotki dannykh, Doklady TUSURa, 2012, No. 2 (26), Part 2, pp. 248-251.

15. Istomina A. A., Badenikov V. Y., Istomin A. L. Optimal'noye upravleniye tovarnymi zapasami na osnove teorii massovogo obsluzhivaniya, FGBOU VO «Angarskiy gosudarstvennyy tekhnicheskiy universitet», 2016, No. 10, pp. 148-152,

16. Jung-Shyr Wu, Jyh-Yeong Wang Refining the diffusion approximation for $\mathrm{M} / \mathrm{G} / \mathrm{m}$ queuing systems with group arrivals, International Journal of Systems Science, 1992, Vol. 23, Issue 1, pp. 127-133. DOI: https://doi.org/10.1080/00207729208949194/.

17. Kazakov A., Lempert A. A., Zharkov M. L. Modelirovaniye transportno-peresadochnykh uzlov na osnove sistem massovogo obsluzhivaniya - mnogofaznykh i c bmappotokom, Vestnik ural'skogo gosudarstvennogo universiteta putey soobshcheniya, 2016, No. 4 (14), pp. 4-14. DOI: https://doi.org/10.20291/2079-0392-2016-4-4-14/.

18. Khinchin A. Ya. Raboty po matematicheskoy teorii massovogo obsluzhivaniya. Pod red. B. V. Gnedenko. Moscow, Fizmatgiz, 1963, 236 p.

19. Kleinrok L. Vychislitel'nyye sistemy s ocheredyami. Moscow, Mir, 1979, 600 p.

20. Klimov G. P. Teoriya massovogo obsluzhivaniya. Moscow, MGU, 2011, $307 \mathrm{p}$.

21. Korolkova L. I., Pereverzev P. P. Optimizatsiya protsessov predpriyatiya na osnove novoy metodiki rascheta kharakteristik mnogofaznoy sistemy massovogo obsluzhivaniya $\mathrm{s}$ nepreryvnoy zagruzkoy bez promezhutochnykh nakopiteley, Sovremennyye problemy nauki i obrazovaniya, 2012, No. 3.

22. Kutselay N. O., Safonov S. V. Obsluzhivaniye neordinarnogo potoka trebovaniy, Molodoy uchenyy, 2018. No. 23, pp. 1-2.

23. Lakatos L., Szeidl L., Telek M. Introduction to queueing systems with telecommunication applications. books.google.com, 2012.

24. Liu Zhongyia, Liu Jingchenb, Zhai Xinb et al. Police staffing and workload assignment in law enforcement using multi-server queueing models, European Journal of Operational Research, 2019, Vol. 276, Issue 2, pp. 614625. DOI: https://doi.org/10.1016/j.ejor.2019.01.004

25. Lozhkovsky A. G. Teoriya massovogo obsluzhivaniya v telekommunikatsiyakh: uchebnik. Odessa, ONAS im. A. S. Popova, $112 \mathrm{p}$.

26. Mandelbaum A., Pats G. State-dependent queues: approximations and applications, Stochastic Networks, IMA Volumes in Mathematics, Springer, 1995, pp. 239-282. 
27. Mandelbaum A., Zeltyn S. The impact of customers patience on delay and abandonment: some empirically driven experiments with the $\mathrm{M} / \mathrm{M} / \mathrm{n}+\mathrm{G}$ queue, Operations Research, 2004, Vol. 26, pp. 377-411.

28. Matveev V. F., Ushakov V. G. Sistemy massovogo obsluzhivaniya. Moscow, Izd-vo MGU, 1984, 242 p.

29. Moiseev A. N., Nazarov A. A.. Beskonechnolineynyye sistemy i seti massovogo obsluzhivaniya. Tomsk, Izd-vo NTL, 2015, $240 \mathrm{p}$.

30. Moiseeva S. P. Razrabotka metodov issledovaniya matematicheskikh modeley nemarkovskikh sistem obsluzhivaniya $\mathrm{s}$ neogranichennym chislom priborov nepuassonovskimi vkhodyashchimi potokami: dis. doktora fiz.-mat. nauk. Tomsk, NI TGU, 2014, 260 p.

31. Pankratova E. V. Issledovaniye matematicheskikh modeley neodnorodnykh beskonechnolineynykh SMO, TSU, 2016 , pp. 1-19.

32. Papadopoulos H. T., Heavey C. Queueing theory in manufacturing systems analysis and design: A classification of models for production and transfer lines, European Journal of Operational Research, 1996, Vol. 92, Issue 1, pp. 1-27. DOI: https://doi.org/10.1016/03772217(95)00378-9

33. Pechinkin A. V. Inversionnyy poryadok obsluzhivaniya $s$ veroyatnostnym prioritetom $\mathrm{v}$ sisteme obsluzhivaniya $\mathrm{s}$ neordinarnym potokom, Matematicheskiye issledovaniya. Ser. Veroyatnost' i prilozheniya, 1989, Vol. 109, pp. 83-94.

34. Plotkin B. K., Delukin L. A. Ekonomiko-matematicheskiye metody i modeli v kommercheskoy deyatel'nosti i logistike: Uchebnik. SPb, Izd-vo, 2015, 345 p.

35. Popov A. V., Obrezanova E. R., Sinebryukhova E. Yu. Veroyatnostnoye modelirovaniye logisticheskoy sistemy gruzoperevozok, Radíoyelektronní í komp’yuterní sistemi, 2012, No. 1 (53), pp. 144-151.

36. Puhalskii A. A., Reed J. E. On many-server queues in heavy traffic, Annals of Applied Probability, 2008, Vol. 20, pp. 129-195.

37. Rachinskaya M. A., Fedotkin M. A. Postroyeniye i issledovaniye veroyatnostnoy modeli tsiklicheskogo upravleniya potokami maloy intensivnosti, Vestnik Nizhegorodskogo universiteta im. N. I. Lobachevskogo, 2014, No. 4 (1), pp. 370-376.

38. Ramaswami V. A. duality theorem for the matrix paradigms in queueing theory, Communications in Statistics. Stochastic Models, 1990, pp. 151-161. DOI: https://doi:10.1080/15326349908807141/.

39. Reed J. E. The G/GI/N queue in the Halfin-Whitt regime I: infinite-server queue system equations, The Stern School, NYU, 2007, pp. 1-59. DOI: https://doi.org/10.1214/09AAP609/.

40. Saaty T. L. Elements of queuing theory: with applications. New York, Dover Pubns, 1983, 423 p.

41. Shakhbazov A. A. Ob odnoy zadache obsluzhivaniya neordinarnogo potoka trebovaniy, Dokl. AN SSSR, 1962, Vol. 145:2, pp. 289-292.

42. Tarasov V. N., Bakhareva N. F., Akhmetshina E. G. Modeli teletrafika na osnove sovremennoy teorii massovogo obsluzhivaniya, Infokommunikatsionnyye tekhnologii, 2018, Vol. 16, № 1, pp. 68-74.

43. Tsitsiashvili G. Sh., Osipova M. A., Samuilov K. E. et al. Primeneniye mnogokanal'nykh sistem massovogo obsluzhivaniya $\mathrm{s}$ otkazami k konstruirovaniyu telekommunikatsionnykh setey, Dal'nevostochnyy matematicheskiy Zhurnal, 2018, Vol. 18:1, pp. 123-126.

44. Tsitsiashvili G. Sh. Invariantnyye svoystva sistem massovogo obsluzhivaniya $\mathrm{s}$ neskol'kimi potokami, Dal'nevostochnyy matematicheskiy zhurnal, 2018, Vol. 18:2, pp. 267-270.

45. Venttsel' Ye. S. Issledovaniye operatsiy. Moscow, Sovetskoye radio, 1972, $552 \mathrm{p}$.

46. Zavanella L., Zanoni S., Ferretti I., et al. Energy demand in production systems: A Queuing Theory perspective, International Journal of Production Economics, 2015, Vol. 170, Part B, pp. 393-400. DOI: https://doi.org/10.1016/j.ijpe.2015.06.019/.

Received 18.06.2019. Accepted 25.10.2019.

УДК 519.872

\section{АНАЛІТИЧНИЙ ОПИС ФІНАЛЬНИХ ІМОВІРНОСТЕЙ СТАНІВ СИСТЕМ МАСОВОГО ОБСЛУГОВУВАННЯ 3 ВХІДНИМ ПОТОКОМ ГРУП ВИМОГ}

Городнов В. П. - д-р військових наук, професор, професор Національної академії Національної гвардії України, Харків, Україна.

Актуальність. Розглянуто три типи систем масового обслуговування: 3 відмовами, 3 обмеженою і 3 необмеженою кількістю місць для очікування в умовах вхідного потоку груп вимог випадкового складу. Об'єктом дослідження були марковськи моделі зазначених систем масового обслуговування. Мета роботи - знайти аналітичний опис фінальних ймовірностей, що дозволяє вирішувати завдання прогнозу ефективності, аналізу і синтезу параметрів зазначених систем.

Метод. Для пошуку фінальних ймовірностей використаний метод еквівалентних перетворень систем лінійно залежних алгебраїчних рівнянь, отриманих граничним переходом 3 диференціальних рівнянь Колмогорова, що описують кожну 3 систем масового обслуговування. Показано, що методи чисельного рішення, які використовуються, засновані на точних значеннях числових параметрів умов роботи систем. Такі параметри відповідають категорії безперервних випадкових величин, точні значення яких можна передбачити 3 вірогідністю строго рівною нулю, що робить чисельний розв'язок позбавленим прогностичних властивостей і не придатним для практики аналізу, синтезу і управління роботою зазначених систем обслуговування. Крім того, в системах обслуговування 3 необмеженим числом місць для очікування кількість рівнянь не обмежена, що виключає можливість їх чисельного рішення.

Результати. Коректність знайдених аналітичних виразів фінальних ймовірностей для станів трьох типів систем масового обслуговування перевірена шляхом виродження потоку груп вимог на вході кожної системи в найпростіший потік вимог. У всіх випадках вираження автоматично переходили в добре відомі формули для систем обслуговування найпростішого потоку вимог. Наведено приклад розрахунків, який вперше чисельно демонструє фізичний зміст змін в роботі систем обслуговування при появі груп вимог в складі вхідного потоку.

(C) Gorodnov V. P., 2019

DOI $10.15588 / 1607-3274-2019-4-3$ 
Висновки. До теперішнього часу спроби опису систем масового обслуговування з вхідним потоком груп вимог відомі тільки для одиничних окремих випадків структури системи і структури вхідного потоку. Розглянутий метод і результати містять повний аналітичний опис фінальних ймовірностей станів для цілого класу систем масового обслуговування 3 вхідним потоком груп вимог: систем $з$ відмовами, з обмеженим числом місць для очікування і 3 нескінченним числом місць для очікування. Ці результати відкривають можливість прогнозу ефективності систем масового обслуговування в діапазоні умов і дозволяють вважати поставлену мету дослідження - досягнутою.

КЛЮЧОВІ СЛОВА: моделі Маркова, системи масового обслуговування, групи вимог.

\section{УДК 519.872 \\ АНАЛИТИЧЕСКОЕ ОПИСАНИЕ ФИНАЛЬНЫХ ВЕРОЯТНОСТЕЙ СОСТОЯНИЙ СИСТЕМ МАССОВОГО ОБСЛУЖИВАНИЯ С ВХОДНЫМ ПОТОКОМ ГРУПП ТРЕБОВАНИЙ}

Городнов В. П. - д-р военных наук, профессор, профессор Национальной академии Национальной гвардии Украины, Харьков, Украина.

АННОТАЦИЯ

Актуальность. Рассмотрены три типа систем массового обслуживания: с отказами, с ограниченным и с неограниченным количеством мест для ожидания в условиях входного потока групп требований случайного состава. Объектом исследования являлись марковские модели отмеченных систем массового обслуживания. Цель работы - найти аналитическое описание финальных вероятностей, позволяющее решать задачи прогноза эффективности, анализа и синтеза параметров отмеченных систем.

Метод. Для поиска финальных вероятностей использован метод эквивалентных преобразований систем линейно зависимых алгебраических уравнений, полученных предельным переходом из дифференциальных уравнений Колмогорова, описывающих каждую из систем массового обслуживания. Показано, что используемые методы численного решения основаны на точных значениях числовых параметров условий работы систем. Такие параметры соответствуют категории непрерывных случайных величин, точные значения которых можно предвидеть с вероятностью строго равной нулю, что делает численное решение лишенным прогностических свойств и не пригодным для практики анализа, синтеза и управления работой отмеченных систем обслуживания. Кроме того, в системах обслуживания с неограниченным числом мест для ожидания количество уравнений не ограничено, что исключает возможность их численного решения.

Результаты. Корректность найденных аналитических выражений финальных вероятностей для состояний трех типов систем массового обслуживания проверена путем вырождения потока групп требований на входе каждой системы в простейший поток требований. Во всех случаях выражения автоматически переходили в хорошо известные формулы для систем обслуживания простейшего потока требований. Приведен пример расчетов, впервые численно демонстрирующий физический смысл изменений в работе систем обслуживания при появлении групп требований в составе входного потока.

Выводы. До настоящего времени попытки описания систем массового обслуживания с входным потоком групп требований известны только для единичных частных случаев структуры системы и структуры входного потока. Рассмотренный метод и результаты содержат полное аналитическое описание финальных вероятностей состояний для целого класса систем массового обслуживания с входным потоком групп требований: систем с отказами, с ограниченным числом мест для ожидания и с бесконечным числом мест для ожидания. Эти результаты открывают возможность прогноза эффективности систем массового обслуживания в диапазоне условий и позволяют считать поставленную цель исследования - достигнутой.

КЛЮЧЕВЫЕ СЛОВА: марковские модели, системы массового обслуживания, группы требований.

\section{ЛІТЕРАТУРА / ЛИТЕРАТУРА}

1. Афанасьева Л. Г. Математические модели транспортных систе, основанные на теории очередей / Л. Г. Афанасьева, Е. В. Булинская // Труды МФТИ. - 2010. - Т. 2, № 4. - С. 6 10

2. Albey E. Multi-dimensional clearing functions for aggregate capacity modeling in multi-stage production systems / E. Albey, U. Bilge, R. Uzsoy // International Journal of Production Research. - 2017. - Vol. 55, Issue 14. - P. 4164-4179. DOI: https://doi.org/10.1080/00207543.2016.1257169/.

3. Asmussen S. R. Random Walks / S. R. Asmussen // Applied Probability and Queues. Stochastic Modelling and Applied Probability. - 2003. - Vol. 51. - P. 220-243. DOI: https://doi:10.1007/0-387-21525-5_8. ISBN 978-0-387-00211$8 /$.

4. Assad A. A. Models for rail transportation / A. A. Assad // Transportation Research Part A: General. - 1980. - Vol. 14, Issue 3. - P. 205-220. DOI: https://doi.org/10.1016/01912607(80)90017-5/.

5. Balsamo S. A review on queueing network models with finite capacity queues for software architecture performance prediction / S. Balsamo, De Nitto V Personè, P. Inverardi // Performance Evaluation. - 2003. - Vol. 51, Issue 2. - P. 269 288. DOI: https://doi.org/10.1016/S0166-5316(02)00099-8/.

(C) Gorodnov V. P., 2019

DOI 10.15588/1607-3274-2019-4-3
6. Бочаров П. П. Теория массового обслуживания / П. П. Бочаров, А. В. Печинкин. - М. : Изд-во РУДН, 1995. $520 \mathrm{c}$.

7. Богоявленская О. Ю. Стационарное распределение длины очереди в системе с неординарным потоком и дисциплиной разделения процессора / О.Ю. Богоявленская // Труды Петрозаводского государственного университета, серия «Математика». - 1996. - Вып. 3. - С. 3-10.

8. Brown L. Statistical Analysis of a Telephone Call Center / [L. Brown, N. Gans, A. Mandelbaum et al.] //Queueing-Science Perspective Journal of the American Statistical Association.2005.- Vol. 100, Issue 469. - P. 36-50. DOI: https://doi.org/10.1198/016214504000001808/.

9. D'Auria B. Stochastic decomposition of the $M / G / \infty$ queue in a random environment / B. D'Auria // Operations Research Letters - 2007. - Vol. 35. - P. 805-812.

10. Doorn E. A. Note on the GI/GI/oo system with identical service and interarrival-time distributions / E. A. Doorn, A. A. Jagers // Journal of queueing systems. - 2004. - Vol. 47. - P. 45-52.

11. Ebadi M. Socio-economic design of control charts for monitoring service processes: a case study of a restaurant system / M. Ebadi, A. Ahmadi-Javid // Journal Quality Technology \& Quantitative Management. - 2018. DOI: https://doi.org/10.1080/16843703.2018.1519880/ 
12. Erlang A. K. The Theory of Probabilities and Telephone Conversations / A. K. Erlang // Nyt Tidsskrift for Mathematic Ser. B 20. - 1909 .

13. Гайдамака Ю. В. Модели обслуживания вызовов в сети сотовой подвижной связи : учебно-методическое пособие Ю. В. Гайдамака, Э. Р. Зарипова, К. Е. Самуйлов. - М. РУДН. $-2008 .-72 \mathrm{p}$.

14. Грачев В. В. Многофазная модель массового обслуживания системы распределенной обработки данных / В.В.Грачев, А. Н. Моисеев, А. А. Назаров и др. // Журнал «Доклады ТУСУР». - 2012.- № 2, Часть 2 (26). - С. 248-251.

15. Истомина А. А. Оптимальное управление товарными запасами на основе теории массового обслуживания / А. А. Истомина, В. Я. Бадеников, А. Л. Истомин // Вестник ангарского государственного технического университета. 2016. - № 10. - C. 148-152.

16. Jung-Shyr Wu Refining the diffusion approximation for $\mathrm{M} / \mathrm{G} / \mathrm{m}$ queuing systems with group arrivals / Wu Jung-Shyr, Wang Jyh-Yeong // International Journal of Systems Science. 1992. - Vol. 23, Issue 1. - P. 127-133. DOI: https://doi.org/10.1080/00207729208949194/.

17. Казаков Л. А. Моделирование транспортно-пересадочных узлов на основе систем массового обслуживания многофазных и с ВМАР-потоком / А. Л. Казаков, А. А. Лемперт, М. Л. Жарков // Вестник Уральского государственного университета путей сообщения. - 2016. № 4 (14). - C. 4-14. DOI: https://doi.org/10.20291/2079-03922016-4-4-14/.

18. Хинчин А. Я. Работы по математической теории массового обслуживания. Под ред. Б. В. Гнеденко / А. Я. Хинчин. М. : Физматгиз, 1963. - 236 с.

19. Клейнрок Л. Вычислительные системы с очередями Л. Клейнрок. - М. : Мир, 1979. - 600 с.

20. Климов Г. П. Теория массового обслуживания / Г. П. Климов. - М. : МГУ, 2011. -307 р.

21. Королькова Л. И. Оптимизация процессов предприятия на основе новой методики расчета характеристик многофазной системы массового обслуживания с непрерывной загрузкой без промежуточных накопителей / Л. И. Королькова, П. П. Переверзев // Современные проблемы науки и образования. - 2012. - № 3 .

22. Куцелай Н. О. Обслуживание неординарного потока требований / Н. О. Куцелай, С. В. Сафонов // Молодой ученый. - 2018. - № 23. - С. 1-2.

23. Lakatos L. Introduction to queueing systems with telecommunication applications / L. Lakatos, L. Szeidl, M. Telek // books.google.com. -2012.

24. Liu Zhongyia Police staffing and workload assignment in law enforcement using multi-server queueing models. / Zhongyia Liu, Jingchenb Liu, Xinb Zhai et al. // European Journal of Operational Research. - 2019. - Vol. 276, Issue 2. - P. 614 625. DOI: https://doi.org/10.1016/j.ejor.2019.01.004

25. Ложковский А. Г. Теория массового обслуживания в телекоммуникациях : учебник / А. Г. Ложковский. - Одесса : ОНАС им. А. С. Попова. -112 c.

26. Mandelbaum A. State-dependent queues: approximations and applications. / A. Mandelbaum, G. Pats // Stochastic Networks, IMA Volumes in Mathematics, Springer. - 1995. - P. 239-282.

27. Mandelbaum A. The impact of customers patience on delay and abandonment: some empirically driven experiments with the $\mathrm{M} / \mathrm{M} / \mathrm{n}+\mathrm{G}$ queue / A. Mandelbaum, S. Zeltyn // Operations Research. - 2004. - Vol. 26. - P. 377-411.

28. Матвеев В. Ф. Системы массового обслуживания. / В. Ф. Матвеев, В. Г. Ушаков. - М. : Изд-во МГУ, 1984. $242 \mathrm{c}$.

29. Моисеев А. Н. Бесконечно линейные системы и сети массового обслуживания / А. Н. Моисеев, А. А. Назаров. Томск : Изд-воНТЛ, 2015. - 240 с.
30. Моисеева С. П. Разработка методов исследования математических моделей немарковских систем обслуживания с неограниченным числом приборов и непуассоновскими входящими потоками: дис. доктора физ.мат. наук / С. П. Моисеева. - Томск : ТГИ, 2014. - 260 с.

31. Панкратова Е. В. Исследование математических моделей неоднородных бесконечнолинейных $\mathrm{CMO}$ Е. В. Панкратова // ТГУ. - 2016. - С. 1-19.

32. Papadopoulos H. T. Queueing theory in manufacturing systems analysis and design: A classification of models for production and transfer lines / H. T. Papadopoulos, C. Heavey // European Journal of Operational Research. - 1996. - Vol. 92, Issue 1. P. 1-27. DOI: https://doi.org/10.1016/0377-2217(95)00378-9

33. Печинкин А. В. Инверсионный порядок обслуживания с вероятностным приоритетом в системе обслуживания с неординарным потоком / А. В. Печинкин // Математические исследования. Сер. Вероятность и приложения. - 1989. T. $109 .-$ C. $83-94$.

34. Плоткин Б. К. Экономико-математические методы и модели в коммерческой деятельности и логистике: Учебник. - СПб. : Изд-во. / Б. К. Плоткин, К. Л. А. Делюкин. - СПб : Изд-во, 2015.-345 c

35. Попов А. В. Вероятностное моделирования логистической системы грузоперевозок / А. В. Попов, Е. Р. Обрезанова, Е. Ю. Синебрюхова // Радіоелектронні і комп'ютерні системи. - 2012. - № 1 (53). - С. 144-151.

36. Puhalskii A. A. On many-server queues in heavy traffic A. A. Puhalskii, J. E. Reed // Annals of Applied Probability. 2008. - Vol. 20. - P. 129-195.

37. Рачинская М. А. Построение и исследование вероятностной модели циклического управления потоками малой интенсивности / М. А. Рачинская, М.А.Федоткин // Вестник Нижегородского университета им Н. И. Лобачевского. - 2014. - № 4 (1). - С. 370-376.

38. Ramaswami V. A duality theorem for the matrix paradigms in queueing theory / V. Ramaswami // Communications in Statistics. Stochastic Models. - 1990. - P. 151-161. DOI: https://doi:10.1080/15326349908807141/.

39. Reed J. E. The G/GI/N queue in the Halfin-Whitt regime I: infinite-server queue system equations / J. E. Reed // The Stern School, NYU. - 2007. - P. 1-59. DOI: https://doi.org/10.1214/09-AAP609/.

40. Saaty T. L. Elements of queuing theory: with applications / T. L. Saaty. - New York : Dover Pubns, 1983. - 423 p.

41. Шахбазов А. А. Об одной задаче обслуживания неординарного потока требований. / А. А. Шахбазов // Докл. АН СССР. - 1962. - Т. 145:2. - С. 289-292.

42. Tarasov V. N. Модели телетрафика на основе современной теории массового обслуживания / В.Н. Тарасов, Н. Ф. Бахарева, Э. Г. Ахметшина // Инфокоммуникационные технологии. - 2018. - Т. 16, № 1. - С. 68-74.

43. Цициашвили Г. Ш. Применение многоканальных систем массового обслуживания с отказами к конструированию телекоммуникационных сетей / Г. Ш. Цициашвили, М. А. Осипова, К. Е. Самуйлов и др. // Дальневост. матем. журн. - 2018. - Т. 18, № 1. - С. 123-126.

44. Цициашвили Г. Ш. Инвариантные свойства систем массового обслуживания с несколькими потоками / Г. Ш. Цициашвили // Дальневосточный математический журнал. - 2018. - Т. 18:2. - С. 267-270.

45. Вентцель Е. С. Исследование операций / Е. С. Вентцель. М. : Советское радио, 1972. - 552 с.

46. Zavanella L. Energy demand in production systems: A Queuing Theory perspective. / L. Zavanella, S. Zanoni, I. Ferretti et al. // International Journal of Production Economics. - 2015. Vol. 170, Part B. - P. 393-400. DOI: https://doi.org/10.1016/j.ijpe.2015.06.019/. 